\title{
Acute myeloid leukemia with 11q23 abnormalities
}

INSERM

\section{Source}

INSERM. (1999). Orphanet: an online rare disease and orphan drug data base. Acute myeloid leukemia with 11q23 abnormalities. ORPHA:98831

Acute myeloid leukemia with 11q23 abnormalities is a tumor of hematopoietic and lymphoid tissues characterized by abnormal proliferation and differentiation of a clonal population of myeloid stem cells carrying unspecific 11q23 abnormalities. Clinical manifestations result from accumulation of malignant myeloid cells within the bone marrow, peripheral blood and other organs, and include leukocytosis, anemia, thrombocytopenia, fatigue, anorexia and weight loss. 